\title{
Production of recombinant porcine IGF-binding protein-5 and its effect on proliferation of porcine embryonic myoblast cultures in the presence and absence of IGF-I and Long-R3-IGF-I
}

\author{
M S Pampusch, G Xi, E Kamanga-Sollo, K J Loseth, \\ M R Hathaway, W R Dayton and M E White
}

Animal Growth and Development Laboratory, Department of Animal Science, University of Minnesota, St Paul, Minnesota 55108, USA

(Requests for offprints should be addressed to M E White, 350 ABLMS, 1354 Eckles Avenue, St Paul, Minnesota 55108, USA; Email: mwhite@umn.edu)

\begin{abstract}
IGF-binding protein-5 (IGFBP-5) is produced by porcine embryonic myogenic cell (PEMC) cultures and is secreted into the medium. IGFBP-5 may play some role in myogenesis and/or in changes in myogenic cell proliferation that accompany differentiation. IGFBP-5 reportedly may either suppress or stimulate proliferation or differentiation of cultured cells depending on cell type and culture conditions. Additionally, IGFBP-5 has been shown to possess both IGF-dependent and IGF-independent actions in some cell types. The goal of this study was to produce recombinant porcine IGFBP-5 (rpIGFBP-5) and assess its IGF-Idependent and IGF-I-independent actions on the proliferation of PEMCs. To accomplish this, we have expressed porcine IGFBP-5 in the baculovirus system, purified and characterized the expressed rpIGFBP-5 and produced an anti-porcine IGFBP-5 antibody that neutralizes the biological activity of porcine IGFBP-5. rpIGFBP-5, purified to $98 \%$ homogeneity using nickel affinity chromatography and IGF-I affinity chromatography, suppressed IGF-Istimulated proliferation of PEMCs in a concentrationdependent manner $(P<0 \cdot 05)$. rpIGFBP-5 also suppressed Long-R3-IGF-I-stimulated proliferation of PEMCs
\end{abstract}

$(P<0 \cdot 05)$, even in the presence of significant molar excess of Long-R3-IGF-I compared with rpIGFBP-5, demonstrating the IGF-independent activity that rpIGFBP-5 possesses in PEMCs, since Long-R3-IGF-I is an IGF analog that has very low affinity for the IGFBPs but retains its ability to bind to the type I IGF receptor and thereby can stimulate proliferation. The anti-rpIGFBP-5 IgY produced against rpIGFBP-5 specifically recognized native porcine IGFBP-5 in PEMC media that also contained porcine IGFBP-2, -3 , and -4 . This antibody is capable of neutralizing the effects of both rpIGFBP-5 and endogenously produced porcine IGFBP-5 on PEMCs as well as detecting IGFBP-5 in Western blots. The production of rpIGFBP-5 and a neutralizing antibody to porcine IGFBP-5 provides a powerful tool to investigate the role of IGFBP-5 in porcine myogenic cell proliferation and differentiation. The data provided here demonstrated that IGFBP-5 has the potential to affect proliferation of PEMCs during critical periods of in vitro muscle cell development and therefore may impact the capacity for ultimate postnatal muscle mass development in vivo.

Journal of Endocrinology (2005) 185, 197-206

\section{Introduction}

Insulin-like growth factors (IGF)-I and -II are potent regulators of both differentiation and proliferation of myogenic cells (Florini et al. 1996, Lawlor \& Rotwein 2000, Tureckova et al. 2001). The availability and actions of IGFs are regulated by members of the IGF-binding protein (IGFBP) family consisting of six proteins that bind IGF-I and -II with high affinity (Clemmons 1998, Hwa et al. 1999, Baxter 2000). Binding of IGF to IGFBPs has been shown to increase the stability of the IGFs and to affect their biological activity (Clemmons 1998, Hwa et al. 1999, Baxter 2000). In addition to their IGFdependent actions, IGFBP-1, -3 , and -5 have been shown to exert IGF-independent actions by binding to cell surfaces (Clemmons 1998, Hwa et al. 1999, Baxter 2000) and IGFBP-3 and -5 possess nuclear localization sequences which suggest that they can travel to the nucleus (Schedlich et al. 2000).

IGFBP-5 has been shown to both stimulate and suppress cell survival, proliferation, and differentiation (Andress \& Birnbaum 1992, James et al. 1996, Ewton et al. 1998, Baxter 2000, Meadows et al. 2000, Yin et al. 2004). Additionally, IGF-independent actions of IGFBP-5 have been demonstrated in various cells types (Andress \& Birnbaum 1992, Schneider et al. 2002). IGFBP-5 reportedly binds to an uncharacterized $420 \mathrm{kDa}$ membrane protein which causes serine phosphorylation when bound 
to IGFBP-5 (Andress 1998). Furthermore, evidence exists indicating that there are mechanisms for nuclear transport of IGFBP-5 and that IGFBP-5 can function as a transcription regulator (Schedlich et al. 1998, Xu et al. 2004). The intracellular transport and nuclear localization of IGFBP-5 as well as putative IGFBP-5 receptors may be responsible for the IGF-independent actions of IGFBP-5 on cells.

IGFBP-5 is produced by myogenic cell lines, porcine embryonic myogenic cells (PEMCs), and porcine muscle satellite cells (Hembree et al. 1996, Johnson et al. 1999, Dahlfors \& Arnqvist 2000, Granata et al. 2000, Jennische \& Hall 2000, Wabitsch et al. 2000, Drivdahl et al. 2001, Kveiborg et al. 2001, Yi et al. 2001). Several studies have shown that IGFBP-5 expression in muscle cell lines is altered during myogenesis and muscle development (James et al. 1996, Gerrard et al. 1999, Cobb et al. 2004), suggesting that IGFBP-5 may play an important role in critical periods of muscle development that may impact postnatal muscle mass. In contrast, IGFBP-5 mRNA levels remain constant in differentiating PEMC cultures (Johnson et al. 2003), raising the possibility that regulation of IGFBP-5 expression and/or function may be different in PEMC cultures than it is in immortalized murine myogenic cell lines. Consequently, the goal of this study was to express porcine IGFBP-5 cDNA (White et al. 1996) in the baculovirus system, purify and characterize the expressed recombinant porcine IGFBP-5 (rpIGFBP-5), and assess the IGF-I-dependent and IGF-Iindependent actions of rpIGFBP-5 on proliferation of cultured porcine myogenic cells. In order to facilitate these investigations, we also have produced and characterized an anti-porcine IGFBP-5 antibody that neutralizes the biological activity of both endogenous and exogenous porcine IGFBP-5.

\section{Materials and Methods}

\section{cDNA production}

The nucleotide sequence of porcine IGFBP-5 was obtained by our laboratory previously (White et al. 1996) (GenBank accession number U41340 from a neonatal porcine skeletal muscle Lamda ZapII cDNA Library prepared by Stratagene Cloning Systems (La Jolla, CA, USA)) and the cDNA was cloned into Bluescript SK phagemids. IGFBP-5 was sequenced in both directions using the dideoxy Sanger termination DNA sequencing method with a ${ }^{35}$ S-labeled dATP (Sanger et al. 1977).

\section{Protein production}

Recombinant IGFBP-5 was produced in a baculovirus expression system by ATG Laboratories Inc. (Eden Prairie, MN, USA). IGFBP-5 cDNA was PCR cloned into the pGEM-T Easy plasmid and then subcloned into the baculovirus transfer vector (pBacHIS3) containing the sequence necessary to add six histidines to the $\mathrm{N}$-terminus (IGFBP-5-6 XHIS). Finally, IGFBP-5-6 XHIS was subcloned into a baculovirus expression vector (pACGP67B) containing a secretion signal. This construct produced rpIGFBP-5 with an N-terminal baculovirus secretion signal and a six-histidine tag on the $\mathrm{N}$ terminus. The recombinant protein was produced in $\mathrm{T}$. ni cells grown in serum-free conditions. Conditioned medium (CM) was collected $48-\mathrm{h}$ post-infection and stored at $-80^{\circ} \mathrm{C}$.

\section{Protein purification}

Nickel-NTA affinity chromatography resin (Qiagen, Valencia, CA, USA) was equilibrated in $10 \mathrm{mM}$ imi-

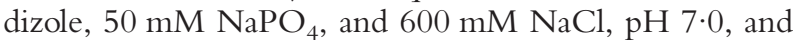
utilized to bind His-tagged rpIGFBP-5. An IGF-I affinity column was made by coupling $2 \mathrm{mg}$ recombinant IGF-I (GroPep, Adelaide, SA, Australia) to Affi-Gel 10 (BioRad Laboratories, Hercules, CA, USA) in $50 \mathrm{mM}$ HEPES, $\mathrm{pH}$ 6.5. The column was run in $50 \mathrm{mM} \mathrm{NaPO}_{4}$ and $600 \mathrm{mM} \mathrm{NaCl}, \mathrm{pH}$ 7·0.

\section{Antibody production}

Polyclonal antibodies to affinity purified IGFBP-5 were produced in chickens by Covance Research Products (Denver, PA, USA) using their standard protocols. The IgY was purified from egg yolk by Eggstact IgY Purification System (Promega Corp., Madison, WI, USA).

\section{Electrophoresis}

Samples were run on 10\% polyacrylamide SDS gels according to the method of Laemmli (1970). Gels were stained with either GelCode Blue Stain (Pierce Chemical Company, Rockford, IL, USA) or with the GelCode Color Silver Stain Kit (Pierce Chemical Company).

\section{Western blotting}

Proteins were electrophoresed on a $10 \%$ polyacrylamide SDS gel and then transferred from the gel to a nitrocellulose membrane in $15 \mathrm{mM}$ Tris, $120 \mathrm{mM}$ glycine, and 5\% methanol overnight at $50 \mathrm{~V}$. After the membrane was rinsed in TBS $(10 \mathrm{mM}$ Tris $-\mathrm{HCl}$ and $150 \mathrm{mM} \mathrm{NaCl}$, $\mathrm{pH} 7 \cdot 4$ ), it was blocked for $1.5 \mathrm{~h}$ in blocking buffer (TBS containing $0 \cdot 1 \%$ Tween 20 plus $3 \%$ bovine serum albumin (BSA)). The membrane was incubated in blocking buffer containing anti-rpIGFBP-5 (1:250) overnight followed by six washes in TBS containing $0 \cdot 1 \%$ Tween 20 . The membrane was then incubated for $1 \mathrm{~h}$ with peroxidaselabeled rabbit anti-chicken IgY (Promega Corp.) (1:5000) in blocking buffer and washed six times with TBS 
containing $0 \cdot 1 \%$ Tween 20 . Bands were detected using Super Signal West Pico Chemiluminescent substrate (Pierce Chemical Company).

\section{Ligand blotting}

Proteins were run on non-reducing SDS-PAGE and then transferred from the gel to a nitrocellulose membrane. Binding proteins were detected with ${ }^{125}$ I-IGF-I (Hembree et al. 1996).

\section{Isolation and culture of PEMCs}

PEMCs for culture were isolated from 50- to 55-day porcine fetuses and stored in liquid nitrogen as described in detail previously (Pampusch et al. 1990, Hembree et al. 1991, 1996). To establish cultures from frozen stocks, rapidly thawed cell suspensions were diluted with the appropriate amount of Dulbecco's modified Eagles' medium (DMEM) containing 7\% (v/v) swine serum (SS) and 3\% (v/v) chicken embryo extract (CEE) and plated in dishes coated with reduced growth factor Basement Membrane Matrigel (BD, Bedford, MA, USA) diluted 1:100 $(\mathrm{v} / \mathrm{v})$ in DMEM. All cultures were maintained at $37^{\circ} \mathrm{C}$ in $5 \% \mathrm{CO}_{2}$ and $95 \%$ air in a water-saturated environment. After a 24-h attachment period, cultures were fed with $10 \mathrm{ml}$ DMEM containing 7\% SS and 3\% CEE.

\section{${ }^{3} H$-thymidine incorporation}

${ }^{3} \mathrm{H}$-thymidine incorporation was measured as previously described (Yang et al. 1999). PEMC cultures were established in $2 \mathrm{~cm}^{2}$ wells as described previously. After $48 \mathrm{~h}$ in culture, serum-containing medium was removed and replaced with a serum-free medium (DMEM containing $250 \mu \mathrm{g}$ IGFBP-free fetuin and $100 \mu \mathrm{g}$ BSA-linoleic $\mathrm{acid} / \mathrm{ml}$ medium) containing IGF-I, Long-R3-IGF-I, rpIGFBP-5, and/or anti-rpIGFBP-5 antibody as indicated in the specific Figure legends Long-R3-IGF-I is an IGF-I analog that has a very low affinity for the IGFBPs but retains its ability to bind to the type I IGF receptor and thereby stimulate proliferation. Consequently, suppression of Long-R3-IGF-I stimulated proliferation by IGFBP-5 is believed to result from IGF-I-independent actions. IGFBP-free fetuin was prepared according to procedures described previously (Yang et al. 1999). After $6 \mathrm{~h}$, the washout medium was removed and $1 \mathrm{ml}$ fresh, serum-free medium identical to the media used in the washout was added to each culture and allowed to incubate for an additional $18 \mathrm{~h}$. After this 24 -h treatment, ${ }^{3} \mathrm{H}$-thymidine was added to the culture media $(1 \mu \mathrm{Ci} / \mathrm{ml}$ final concentration) and allowed to incubate at $37^{\circ} \mathrm{C}$ for $3 \mathrm{~h}$. Cells were rinsed with cold serum-free DMEM and fixed with $1 \mathrm{ml}$ cold $5 \%$ trichloroacetic acid (TCA) overnight at $4{ }^{\circ} \mathrm{C}$. Unincorporated ${ }^{3} \mathrm{H}$-thymidine was removed by aspirating the cold 5\% TCA and rinsing wells with additional cold $5 \%$ TCA. ${ }^{3} \mathrm{H}$-thymidine incorporation into cellular DNA was measured by dissolving cell material in $0.5 \mathrm{M} \mathrm{NaOH}$ and counting it in a scintillation counter. All data points are the average of values obtained from triplicate cultures and are representative of duplicate or triplicate assays.

\section{Statistical analysis}

All data were analyzed using the mixed procedure of SAS (SAS 2001). All data points are the average of values obtained from triplicate cultures and are representative of duplicate or triplicate assays. When significant interactions were detected $(P<0 \cdot 05)$, least squares means were separated using Fischer's LSD test $(P<0 \cdot 05)$.

\section{Results}

\section{Expression and purification of rpIGFBP-5}

Medium conditioned for $48 \mathrm{~h}$ by T. ni cells infected with baculovirus containing the rpIGFBP-5 construct contained rpIGFBP-5 that could be detected using ${ }^{125}$ I-IGF-I ligand blotting. This medium was dialyzed for $24 \mathrm{~h}$ against $10 \mathrm{mM}$ imidizole, $50 \mathrm{mM} \mathrm{NaPO}_{4}$, and $600 \mathrm{mM} \mathrm{NaCl}$, $\mathrm{pH} 7 \cdot 0$, and then for an additional $24 \mathrm{~h}$ against the same buffer at $\mathrm{pH} 8 \cdot 0$. The dialyzed, CM was mixed with nickel-NTA affinity chromatography resin for $1.5 \mathrm{~h}$ and then poured into a column. The column was washed with 3 column volumes of $15 \mathrm{mM}$ imidizole, $50 \mathrm{mM} \mathrm{NaPO}_{4}$, and $600 \mathrm{mM} \mathrm{NaCl}, \mathrm{pH} 8 \cdot 0$, and the rpIGFBP-5 was then eluted with $50 \mathrm{mM}$ imidizole, $50 \mathrm{mM} \mathrm{NaPO}_{4}$, and $600 \mathrm{mM} \mathrm{NaCl}, \mathrm{pH} 8 \cdot 0$. A silver-stained SDS polyacrylamide gel showed that although rpIGFPB-5 was greatly enriched in the column eluate as compared with the culture media significant contaminants remained (Fig. 1). In order to further purify the nickel column eluate, its $\mathrm{pH}$ was lowered to $7 \cdot 4$ by the addition of $1 \mathrm{M} \mathrm{HCl}$ and it was loaded onto an IGF-I affinity column. The column was washed with 5 column volumes of column buffer $(50 \mathrm{mM}$ $\mathrm{NaPO}_{4}$ and $600 \mathrm{mM} \mathrm{NaCl}, \mathrm{pH} 7 \cdot 0$ ), 2 column volumes of column buffer without $\mathrm{NaCl}$, and $0 \cdot 5$ column volumes of $1 \cdot 0 \%(\mathrm{v} / \mathrm{v})$ acetic acid prior to elution of IGFBP-5 with 3 column volumes of $1 \cdot 0 \%(\mathrm{v} / \mathrm{v})$ acetic acid. Silver-stained SDS polyacrylamide gels showed that the rpIGFBP-5 fraction eluted from the IGF-I affinity column in $1.0 \%$ $(\mathrm{v} / \mathrm{v})$ acetic acid contained a single protein band migrating at $37 \mathrm{kDa}$ in a reducing SDS-PAGE gel (Fig. 1). Scanning densitometry showed that more than $98 \%$ of the protein in this fraction was in the rpIGFBP-5 band. This protein ran as a doublet on silver-stained non-reducing SDS-PAGE and was identified as IGFBP-5 based on its ability to bind ${ }^{125}$ I-IGF-I in the ligand blot assay (Fig. 2) which was performed on non-reducing SDS-PAGE. The two rpIGFBP-5 bands observed using non-reducing SDS-PAGE ran at 


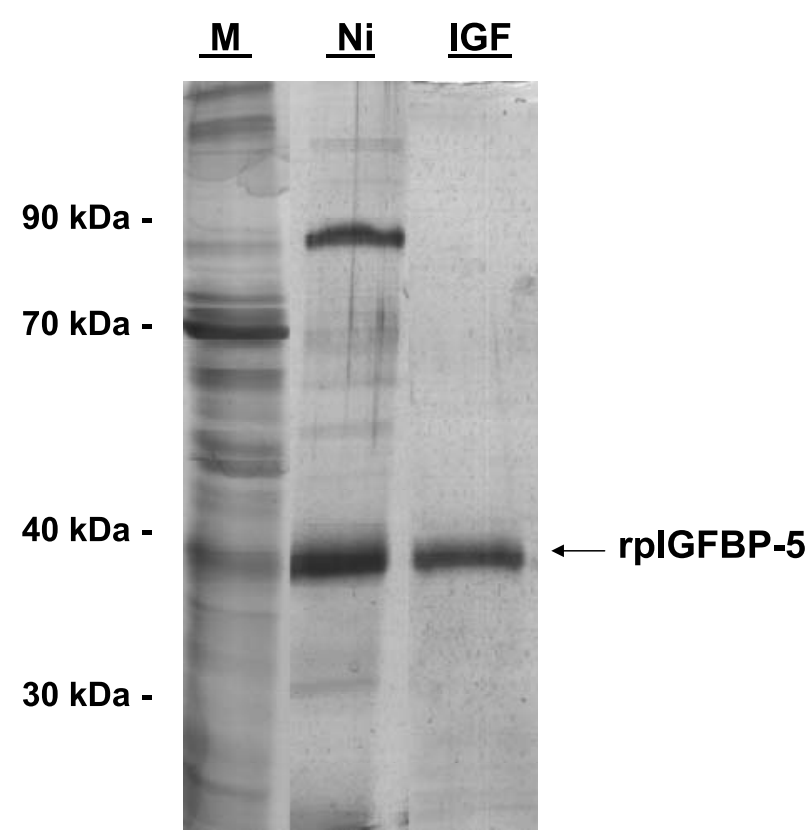

Figure 1 Reduced, silver-stained, 10\% polyacrylamide gel of T. ni cell medium and rpIGFBP-5-containing fractions obtained at various steps in the purification of rpIGFPB-5. M, T. ni cell medium; Ni, rpIGFBP-5 fraction eluting from the nickel-NTA affinity column; IGF, rpIGFBP-5 fraction eluting from the IGF-I affinity column. The rplGFBP-5 band migrates at approximately $37 \mathrm{kDa}$.

apparent molecular sizes of approximately 34 and $28 \mathrm{kDa}$. Both rpIGFBP-5 bands observed in non-reducing SDSPAGE ligand blots were capable of binding ${ }^{125}$ I-IGF-I and are likely conformation and/or glycosylation variants of rpIGFBP-5 that run at similar molecular weights under reducing conditions. Approximately $5 \mathrm{mg}$ purified rpIGFBP-5 could be isolated from 1 liter of cell culture medium.

\section{Effect of rpIGFBP-5 on IGF-I-stimulated proliferation of PEMC cultures}

Figure 3 demonstrates that when IGF-I and rpIGFBP-5 were added simultaneously to PEMC cultures, rpIGFBP-5 suppressed IGF-I (1.3 nM)-stimulated proliferation in a concentration-dependent manner. Most of the IGF-stimulated proliferation was suppressed when 1-2.7 nM rpIGFBP-5 was added to $1.3 \mathrm{nM}$ IGF-I.

\section{Effect of rpIGFBP-5 on Long-R3-IGF-I-stimulated proliferation of PEMC cultures}

In order to assess the IGF-I-independent activity of rpIGFBP-5 in PEMC cultures, we examined its ability to inhibit Long-R3-IGF-I-stimulated proliferation. LongR3-IGF-I is an IGF-I analog that has very low affinity for the IGFBPs but retains its ability to bind to the type I IGF receptor and thereby stimulate proliferation. Conse-

\section{Non-Reduced}

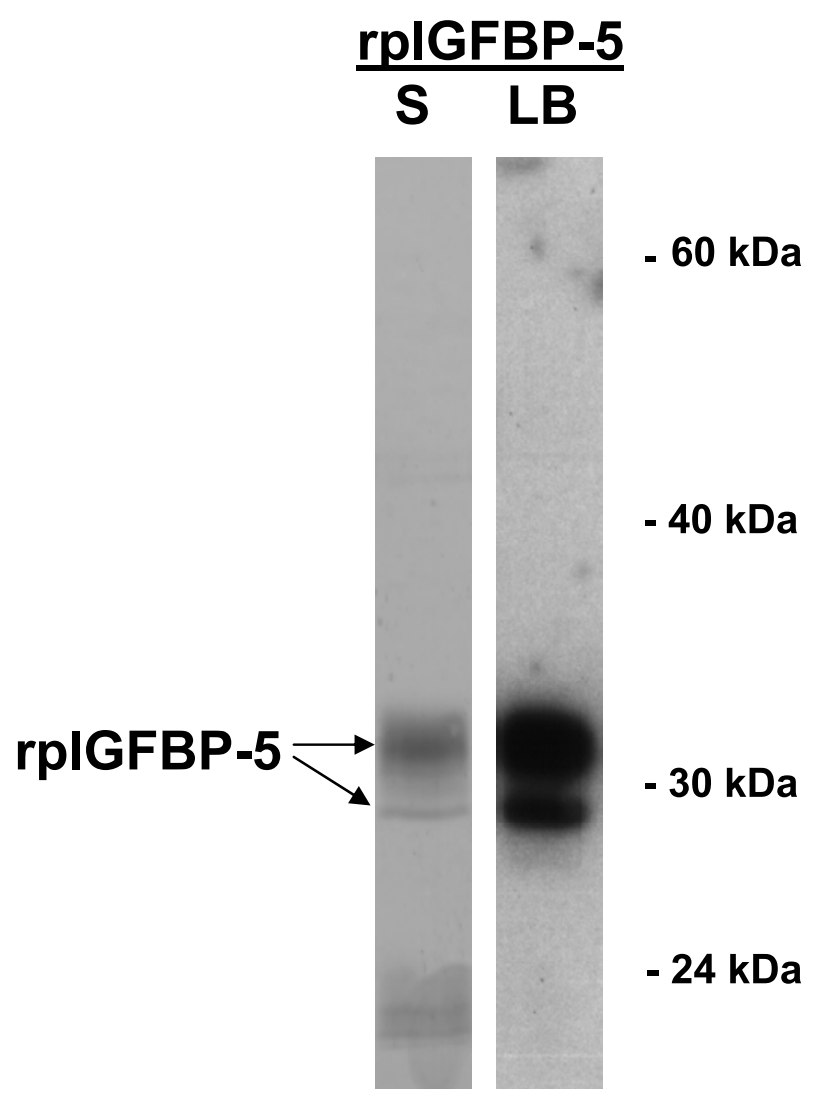

Figure 2 Non-reduced, silver-stained, 10\% polyacrylamide gel (S) and ${ }^{125}$ I-IGF-I Western ligand blot (LB) of purified rpIGFBP-5. Non-reduced rpIGFBP-5 appears as a doublet with apparent molecular weights of approximately 34 and $28 \mathrm{kDa}$.

quently, suppression of Long-R3-IGF-I-stimulated proliferation by IGFBP-5 is believed to result from IGF-Iindependent actions of IGFBP-5 with the cell rather than binding and inactivation of IGF-I. Figure 4a shows that rpIGFBP-5 suppressed Long-R3-IGF-I-stimulated proliferation in PEMC cultures in a concentration-dependent manner. Significant suppression of Long-R3-IGF-Istimulated proliferation was observed when rpIGFBP-5 was added in the same equimolar quantities as Long-R3IGF-I. However, compete suppression was not observed until an eightfold molar excess of rpIGFBP-5 was added. In order to ensure that the suppression of Long-R3-IGFI-stimulated proliferation in PEMCs by rpIGFBP-5 was not due to weak interaction of rpIGFBP-5 with LongR3-IGF-I, we incubated PEMCs in a molar excess of Long-R3-IGF-I (20 nM) compared with rpIGFBP-5 $(13.5 \mathrm{nM})$. These data indicated that rpIGFBP-5 was able to suppress Long-R3-IGF-I-stimulated proliferation even 


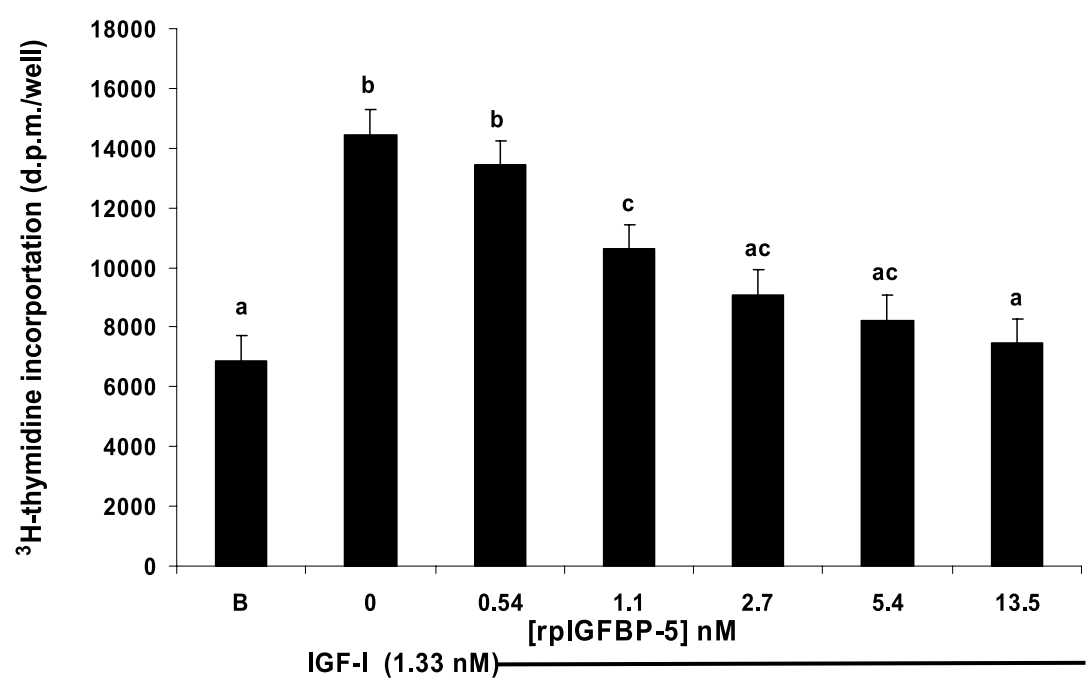

Figure 3 Effect of rpIGFBP-5 on IGF-I-stimulated proliferation of PEMCs. The bar labeled B shows ${ }^{3} \mathrm{H}$-thymidine incorporation in cultures treated for $24 \mathrm{~h}$ with basal medium containing no IGF-I. All other bars represent ${ }^{3} \mathrm{H}$-thymidine incorporation into cultures treated for $24 \mathrm{~h}$ with $1.33 \mathrm{nM}$ IGF-I and the indicated concentration of rplGFBP-5 prior to measuring ${ }^{3} \mathrm{H}$-thymidine incorporation as described in Materials and Methods. Values with different letters are different from each other $(P<0 \cdot 05)$.

in the presence of a large excess of Long-R3-IGF-I. This result indicated that rpIGFBP-5 was not suppressing Long-R3-IGF-I-stimulated proliferation by weakly interacting with and sequestering Long-R3-IGF-I away from the cells preventing it from binding to the type I IGF receptor (Fig. 4b). Rather, rpIGFBP-5 was instead functioning through an IGF-independent mechanism. In order to further confirm that rpIGFBP-5 does not bind and inactivate Long-R3-IGF-I, data from our laboratory have demonstrated that rpIGFBP-5 affects IGF-I-stimulated proliferation and differentiation of L6 myoblasts but does not affect Long-R3-IGF-I-stimulated proliferation or differentiation (data not shown). These data confirm previous reports by Ewton et al. (1998). Furthermore, others have reported that IGFBP-5 does not inhibit Long-R3-IGF-Istimulated phosphorylation of insulin receptor substrate (IRS), establishing that the IGF-I receptor is still activated by Long-R3-IGF-I when IGFBP-5 is present (Ricort \& Binoux 2002). Furthermore, McCusker \& Novakofski (2004) have demonstrated that ${ }^{125}$ I-Long-R3-IGF-I does not bind to IGFBP-5 and that IGFBP-5 does not affect the binding of ${ }^{125}$ I-Long-R3-IGF-I to the type 1 IGF receptor. Taken together, we feel that our data and a large body of supporting literature have established the functionality of rpIGFBP-5 and that rpIGFBP-5 does not bind to Long-R3-IGF-I making it unavailable to the type I IGF receptor.

\section{Characterization of anti-IGFBP-5 antibody}

Because the amino acid sequence homology between porcine IGFBP-5 and other mammalian IGFBP-5 is so highly conserved, we chose chickens as the species to produce antibodies against rpIGFBP-5. Purified rpIGFBP-5 was used to elicit antibody production in chickens and anti-IGFBP-5 IgY was isolated as described in Materials and Methods. Western immunoblots showed that anti-IGFBP-5 IgY recognizes rpIGFBP-5 (Fig. 5). Western immunoblots of PEMC CM demonstrated that anti-IGFBP-5 can specifically recognize the endogenously produced $28 \mathrm{kDa}$ porcine IGFBP-5 protein (Fig. 6). CM was obtained from PEMCs that had been incubated in the basal media described in Materials and Methods containing Long-R3-IGF-I and transforming growth factor- $\beta$ which has been shown to enhance IGFBP-5 production in porcine muscle cells (Yi et al. 2001, Johnson et al. 2003). As demonstrated by ${ }^{125} \mathrm{I}-\mathrm{IGF}-\mathrm{I}$ ligand blots in Fig. 6, this $\mathrm{CM}$ also contained IGFBP-2, -3 , and -4 in addition to porcine IGFBP-5, yet anti-rpIGFBP-5 IgY only recognized the endogenous porcine IGFBP- 5 confirming the specificity of the antibody. Anti-IGFBP-5 also recognized a protein banding at approximately $17 \mathrm{kDa}$ which does not bind ${ }^{125}$ I-IGF-I and is most likely an IGFBP-5 fragment. ${ }^{125}$ I-IGF-I ligand blots of PEM CM also showed a light, $30 \mathrm{kDa}$ IGFBP-5 band (Fig. 6) that does not show up on the anti-IGFBP-5 Western blot of PEM CM. This is likely because the quantity of IGFBP-5 in this band is beyond the detection threshold of the Western blot.

Neutralization of IGFBP-5 suppression of PEMC proliferation by anti-rpIGFBP-5 $\operatorname{Ig} Y$

Anti-rpIGFBP-5 was able to suppress the ability of rp-IGFBP-5 to inhibit IGF-I-dependent proliferation in 
(a)

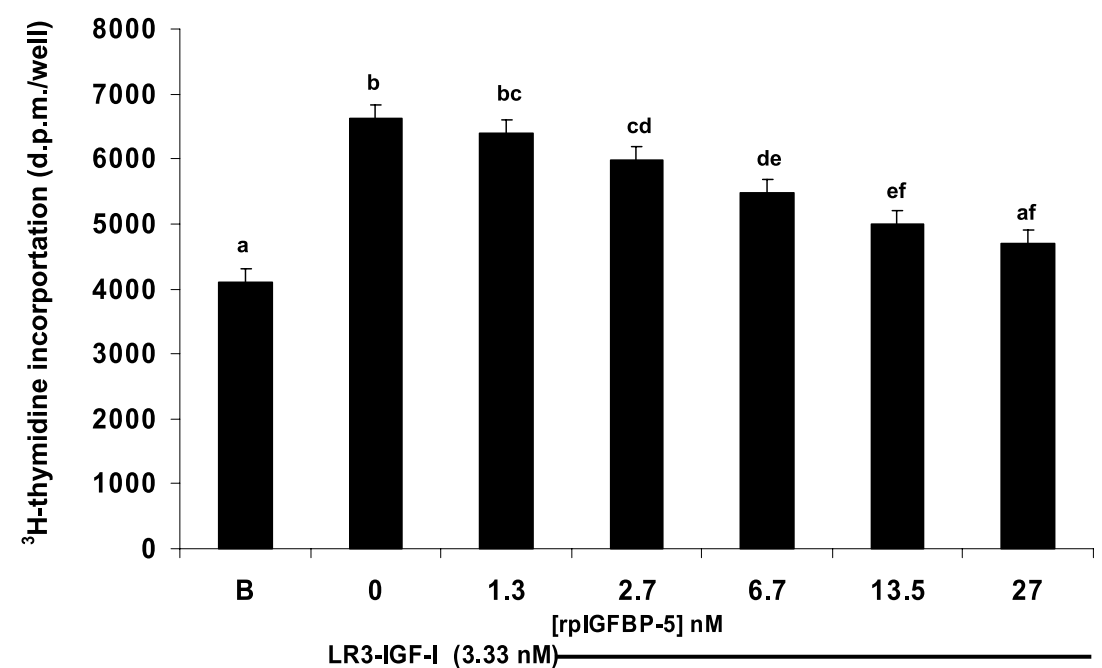

(b)

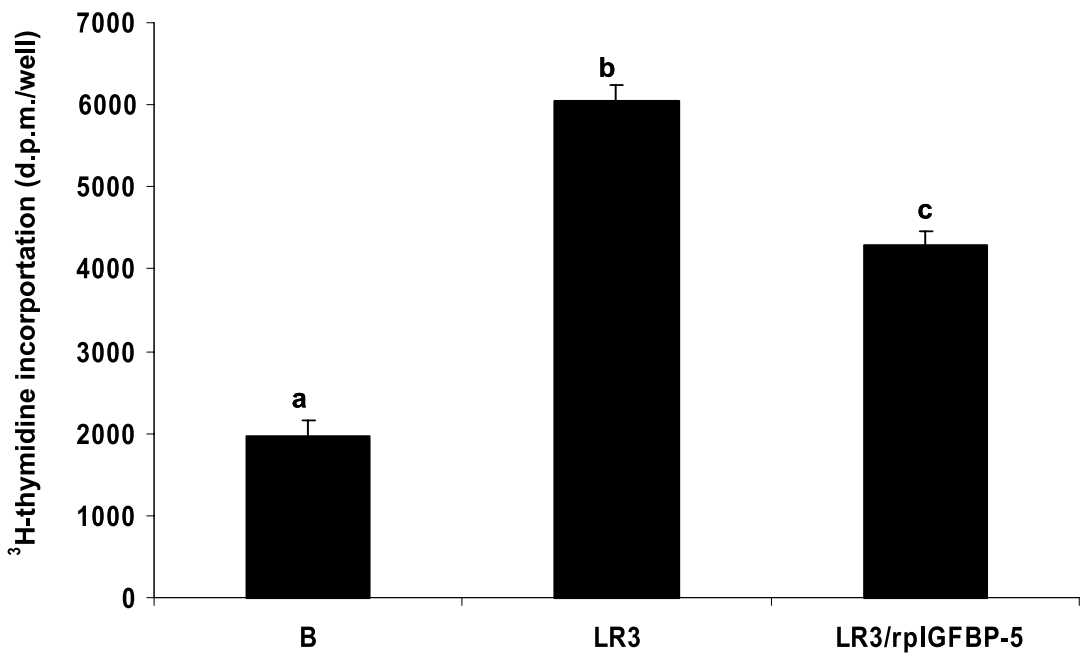

Figure 4 (a) Effect of rpIGFBP-5 on Long-R3-IGF-I (LR3-IGF-I)-stimulated proliferation of PEMCs. The bar labeled B shows ${ }^{3} \mathrm{H}$-thymidine incorporation in cultures treated for $24 \mathrm{~h}$ with basal medium containing no Long-R3-IGF-I. All other bars represent ${ }^{3} \mathrm{H}$-thymidine incorporation into cultures treated for $24 \mathrm{~h}$ with $3.33 \mathrm{nM}$ Long-R3-IGF-I and the indicated concentration of rpIGFBP-5 prior to measuring ${ }^{3} \mathrm{H}$-thymidine incorporation as described in Materials and Methods. Since Long-R3-IGF-I has very little affinity for IGFBPs, the effects of rpIGFBP-5 on Long-R3-IGF-I-stimulated proliferation of PEMCs is likely to be an IGF-independent effect of rpIGFBP-5. Values with different letters are different from each other $(P<0 \cdot 05)$. (b) Effect of rpIGFBP-5 on PEMC proliferation in the presence of a large excess ( $5 \mathrm{nM}$ ) of Long-R3-IGF-I. B, cultures were treated for $24 \mathrm{~h}$ with basal medium prior to measuring ${ }^{3} \mathrm{H}$-thymidine incorporation; LR3, cultures were treated for $24 \mathrm{~h}$ with basal medium containing $20 \mathrm{nM}$ Long-R3-IGF-I prior to measuring ${ }^{3} \mathrm{H}$-thymidine incorporation; LR3/rpIGFBP-5, cultures were treated for $24 \mathrm{~h}$ with basal medium containing $20 \mathrm{nM}$ Long-R3-IGF-I and $13.5 \mathrm{nM}$ rplGFBP-3 prior to measuring ${ }^{3} \mathrm{H}$-thymidine incorporation. Values with different letters are different from each other $(P<0 \cdot 05)$. 


\section{rpIGFBP-5}

\section{Non-Reduced}

\section{$60 \mathrm{kDa}-$}

$40 \mathrm{kDa}$ -

$30 \mathrm{kDa}-$

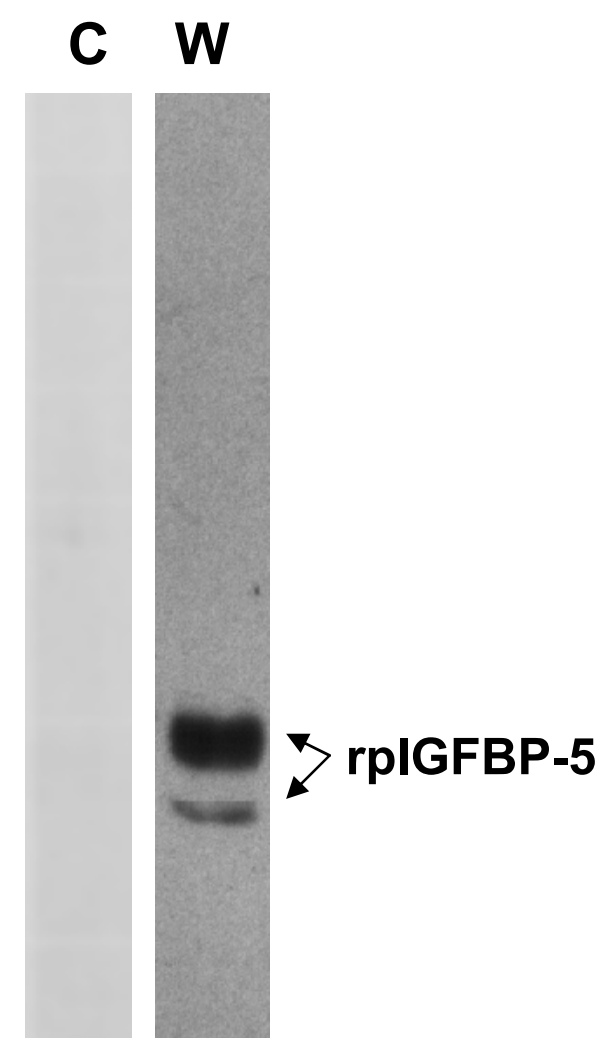

Figure 5 Anti-IGFBP-5 Western blots (W) of non-reduced rpIGFBP-5 and a control lane (C) that was incubated with non-specific IgY before the secondary antibody.

PEMC cultures (Fig. 7) as well as IGF-independent proliferation of PEMCs (data not shown). Non-immune IgY up to $1200 \mu \mathrm{g} / \mathrm{ml}$ had no effect on proliferation of PEMC cultures, thus establishing that the effects of the anti-rpIGFBP-5 IgY are specific. Furthermore, antirpIGFBP-5 $\operatorname{IgY}$ was able to neutralize the ability of endogenous porcine IGFBP-5 in PEM CM to inhibit proliferation in PEMC cultures (Fig. 8). These data demonstrated that both endogenous porcine IGFBP-5 and exogenously added rpIGFBP-5 have the same biological actions in PEMCs and that immunoneutralization of either exogenous rpIGFBP-5 or endogenous porcine IGFBP-5 increases the proliferation of PEMCs.

\section{Discussion}

We have utilized a baculovirus expression system to produce $\mathrm{mg}$ quantities of rpIGFBP-5, purified the

\section{PEM CM}

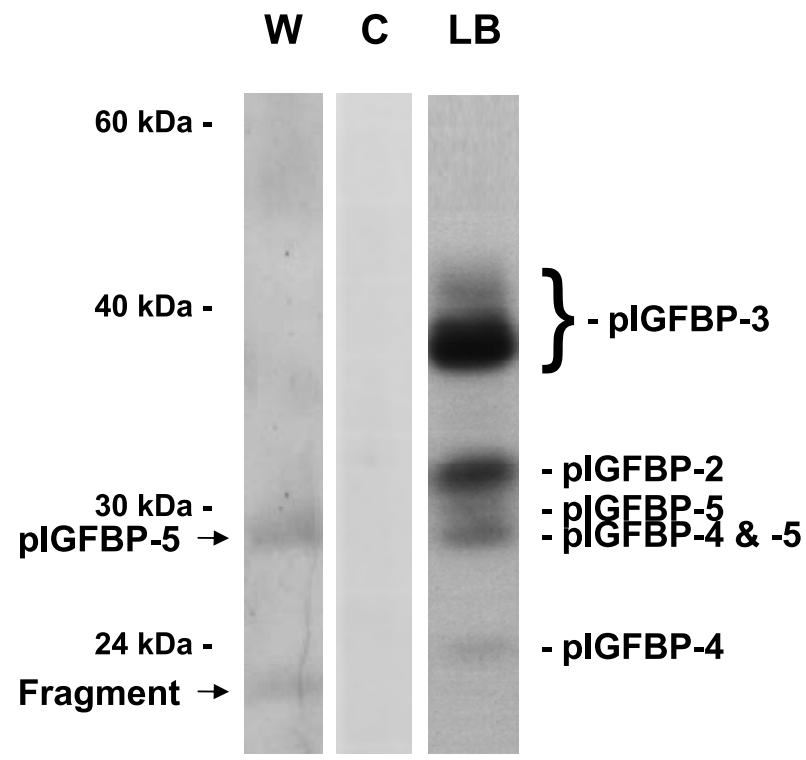

Figure 6 Anti-IGFBP-5 Western blots (W) and ${ }^{125}$ I-IGF-I Western ligand blot (LB) of PEM CM. Control lane (C) is a negative control lane of PEM CM that was incubated with non-specific IgY before the secondary antibody. Non-reduced native porcine IGFBP-5 in the PEM CM appears as a light band at approximately $28 \mathrm{kDa}$ and a fragment that appears to be less than $17 \mathrm{kDa}$. The very light $30 \mathrm{kDa}$ IGFBP-5 band indicated in the ligand blot is not observed in the Western blot likely because the quantity of this molecular weight IGFBP-5 band is beyond the detection limits of anti-IGFBP-5 Western blot assay.

rpIGFBP-5 to greater than 98\% homogeneity using nickel and IGF-I affinity chromatography and demonstrated its ability to bind IGF-I. In addition, we have shown that IGFBP-5 suppresses proliferation of cultured myogenic cells via both IGF-I-dependent and IGF-I-independent mechanisms.

Finally, purified rpIGFBP-5 has been used to elicit production of an anti-rpIGFBP-5 antibody that is able to neutralize the actions of both rpIGFBP-5 and endogenously produced porcine IGFBP-5.

IGFBP-5 expression remains constant during the differentiation of PEMC cultures (Johnson et al. 2003); however, several studies have shown that IGFBP-5 expression in muscle cell lines is altered during myogenesis and muscle development (James et al. 1996, Gerrard et al. 1999, Cobb et al. 2004). This observation raises the possibility that the regulation of IGFBP-5 expression and/or function may be different in PEMC cultures than it is in immortalized murine myogenic cell lines.

Many studies have shown that IGFBP-5 can have either stimulatory and/or inhibitory actions on cell proliferation that may be tissue specific or dependent on culture conditions (Schneider et al. 2002). Several studies have 


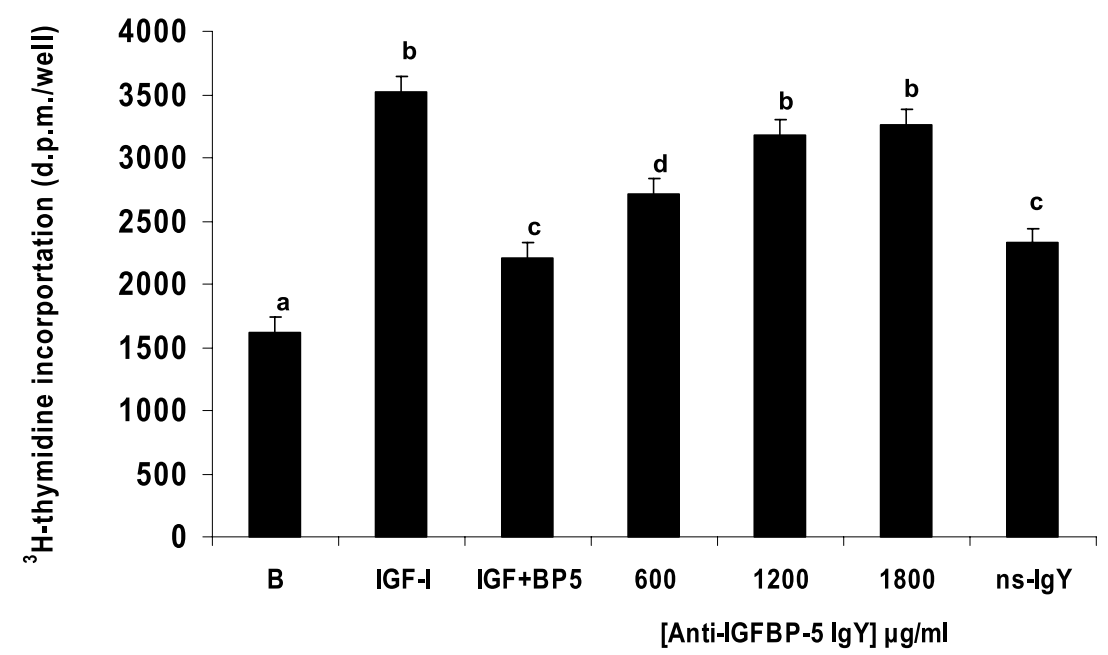

Figure 7 Effect of anti-IGFBP-5 IgY on the ability of rpIGFPB-5 to suppress IGF-I-stimulated proliferation of PEMC cultures. IGF-I, ${ }^{3} \mathrm{H}$-thymidine incorporation stimulated by treatment with $1.33 \mathrm{nM}$ IGF-I; IGF+BP5, ${ }^{3} \mathrm{H}$-thymidine incorporation in the presence of $1.33 \mathrm{nM}$ IGF-I and $2.7 \mathrm{nM}$ rpIGFBP-5; 600, 1200, and $1800,{ }^{3} \mathrm{H}$-thymidine incorporation in the presence of $1.33 \mathrm{nM} \mathrm{IGF-I} \mathrm{and} 2.7 \mathrm{nM}$ rpIGFBP-5 plus the indicated quantity of anti-rplGFBP-3 IgY $(\mu \mathrm{g} / \mathrm{ml})$; ns-lgY (non-specific IgY, $1200 \mu \mathrm{g} / \mathrm{ml}),{ }^{3} \mathrm{H}$-thymidine incorporation in the presence of $1.33 \mathrm{nM}$ IGF-I and $2.7 \mathrm{nM}$ rplGFBP-5 plus $1200 \mu \mathrm{g}$ non-immune $\mathrm{IgY} / \mathrm{ml}$. Values with different letters are different from each other $(P<0.05)$.

shown that IGFBP-5 binds IGF-I and effectively makes it unavailable to the type I IGF-I receptor (Jones \& Clemmons 1995, Xu et al. 2004), resulting in suppression of IGF-I-stimulated proliferation. This suppression is referred to as IGF dependent because it requires that IGFBP-5 bind IGF-I. Our data have shown that rpIGFBP-5 suppresses IGF-I-stimulated proliferation of PEMC cultures in a concentration-dependent manner. Significant suppression of IGF-I-stimulated proliferation

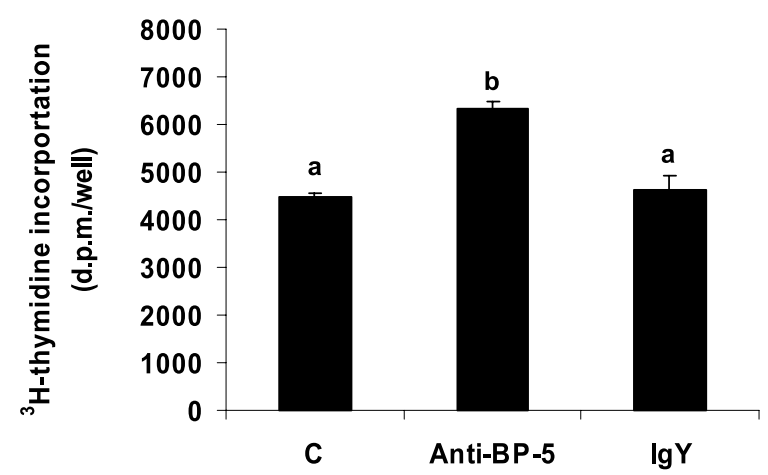

Figure 8 Immunoneutralization of endogenous porcine IGFBP-5 results in increased proliferation rate in PEMC cultures. C, ${ }^{3} \mathrm{H}$-thymidine incorporation of PEMCs in $\mathrm{CM}$ containing endogenous porcine IGFBP-5 (Fig. 6); Anti-BP-5, ${ }^{3} \mathrm{H}$-thymidine incorporation in the presence of $1200 \mu \mathrm{g} / \mathrm{ml}$ anti-IGFBP-5 IgY; IgY, ${ }^{3} \mathrm{H}$-thymidine incorporation of PEMCs in CM in the presence of $1200 \mu \mathrm{g} / \mathrm{ml}$ non-specific IgY. Values with different letters are different from each other $(P<0 \cdot 05)$. was observed at equimolar concentrations of IGF-I and rpIGFBP-5 and at a twofold excess of rpIGFBP-5 to IGF-I. ${ }^{3} \mathrm{H}$-thymidine incorporation was not different from basal media. These data have established that rpIGFBP-5 has IGF-dependent activity in the PEMC system.

It has also been demonstrated in many tissue and cell types that IGFBP-5 possesses IGF-independent actions (Schneider et al. 2002). In order to assess the IGF-Iindependent activity of rpIGFBP-5 in PEMC cultures, we examined its ability to inhibit Long-R3-IGF-I-stimulated proliferation in these cultures. Long-R3-IGF-I is an IGF-I analog that has very low affinity for the IGFBPs but retains its ability to bind to the type I IGF receptor and thereby stimulate proliferation (Schneider et al. 2001). Consequently, suppression of Long-R3-IGF-I-stimulated proliferation by IGFBP-5 is believed to result from IGF-I-independent actions of IGFBP-5 on the cell rather than binding and modulation of IGF-I. Further confirmation of this comes from Ewton et al. (1998) and data from our laboratory demonstrating that rpIGFBP-5 affects IGF-I-stimulated proliferation and differentiation of L6 myoblasts but does not affect Long-R3-IGF-I-stimulated proliferation or differentiation. If rpIGFBP-5 could bind Long-R3-IGF-I, it should also be able to affect Long-R3IGF-I-stimulated proliferation and differentiation of L6 myoblasts, since IGF-I and Long-R3-IGF-I both function through the type 1 IGF receptor. Furthermore, others have reported that IGFBP-5 does not inhibit Long-R3IGF-I-stimulated phosphorylation of IRS, establishing that 
the IGF-I receptor is still activated by Long-R3-IGF-I when IGFBP-5 is present (Ricort \& Binoux 2002). Moreover, McCusker \& Novakofski (2004) have demonstrated that ${ }^{125}$ I-Long-R3-IGF-I does not bind to IGFBP-5 and that IGFBP-5 does not affect the binding of ${ }^{125}$ I-Long-R3-IGF-I to the type 1 IGF receptor. Taken together, we feel that our data and a large body of supporting literature have established the IGF-independent functionality of rpIGFBP-5. Since rpIGFBP-5 suppresses Long-R3-IGF-I-stimulated proliferation of PEMC cultures in a concentration-dependent manner, even when excess Long-R3-IGF-I is present, our data and the supporting literature strongly suggest that rpIGFBP-5 possesses IGF-independent activity in this culture system. These data also suggest that PEMCs possess receptors for IGFBP-5; however, the identity of these receptors is currently unknown.

The polyclonal antibody specific for rpIGFBP-5 was able to neutralize the activity of exogenous rpIGFBP-5 and recognized the $28 \mathrm{kDa}$ native IGFBP-5 band endogenously produced by PEMCs. In addition, the anti-rpIGFBP-5 IgY was able to neutralize the ability of endogenous porcine IGFBP-5 in PEMC CM to inhibit proliferation in PEMC cultures. These data demonstrated that both endogenous porcine IGFBP-5 and exogenously added rpIGFBP-5 have the same biological actions in PEMCs and that immunoneutralization of either of these increases the proliferation of PEMCs.

PEMC CM also contains a light, $30 \mathrm{kDa}$ IGFBP-5 band that did not show up on the anti-IGFBP-5 Western blot of PEMC CM. This is likely because the quantity of IGFBP-5 in this band is beyond the detection threshold of the Western blot. Although this antibody has a low titer requiring the use of larger concentrations, there is no affect of similar quantities of non-specific IgY. Therefore this antibody can be a useful reagent in studying the effects of endogenous IGFBP-5 on proliferation and differentiation of PEMC cultures.

In summary, we have purified rpIGFBP-5 and it appears to have significant effects on porcine myogenic cells similar to those reported for murine myogenic cell lines. Recombinantly produced porcine IGFBP-5 affects proliferation of cultured PEMCs via both IGF-Idependent and IGF-I-independent mechanisms. IGFindependent effects of IGFBP-5 have not been previously reported for skeletal muscle myogenic cells. These data have established that IGFBP-5 produced by myogenic cells has the potential to affect proliferation of embryonic myogenic cells during critical periods of muscle development that may impact the ultimate muscle mass achievable postnatally.

\section{Funding}

This research was funded in part by NRI Competitive Grants Program/USDA Grant No. 00-03271. This is published as a paper of the scientific journal series of the Minnesota Agricultural Experimental Station on research conducted under the Minnesota Agricultural Experimental Station project no. 16-060. The authors declare that there is no conflict of interest that would prejudice the impartiality of this scientific work.

\section{References}

Andress DL 1998 Insulin-like growth factor-binding protein-5 (IGFBP-5) stimulates phosphorylation of the IGFBP-5 receptor. American Journal of Physiology - Endocrinology and Metabolism 274 E744-E750.

Andress DL \& Birnbaum RS 1992 Human osteoblast-derived insulin-like growth factor (IGF) binding protein-5 stimulates osteoblast mitogenesis and potentiates IGF action. Journal of Biological Chemistry $26722467-22472$.

Baxter RC 2000 Insulin-like growth factor (IGF)-binding proteins: interactions with IGFs and intrinsic bioactivities. American Journal of Physiology - Endocrinology and Metabolism 278 E967-E976.

Clemmons DR 1998 Role of insulin-like growth factor binding proteins in controlling IGF actions. Molecular and Cellular Endocrinology 140 19-24.

Cobb LJ, Salih DA, Gonzalez I, Tripathi G, Carter EJ, Lovett F, Holding C \& Pell JM 2004 Partitioning of IGFBP-5 actions in myogenesis: IGF-independent anti-apoptotic function. Journal of Cell Science 117 1737-1746.

Dahlfors G \& Arnqvist HJ 2000 Vascular endothelial growth factor and transforming growth factor-beta1 regulate the expression of insulin-like growth factor-binding protein-3, -4 , and -5 in large vessel endothelial cells. Endocrinology 141 2062-2067.

Drivdahl RH, Sprenger C, Trimm K \& Plymate SR 2001 Inhibition of growth and increased expression of insulin-like growth factorbinding protein-3 (IGFBP-3) and -6 in prostate cancer cells stably transfected with antisense IGFBP-4 complementary deoxyribonucleic acid. Endocrinology 142 1990-1998.

Ewton DZ, Coolican SA, Mohan S, Chernausek SD \& Florini JR 1998 Modulation of insulin-like growth factor actions in L6A1 myoblasts by insulin-like growth factor binding protein (IGFBP)-4 and IGFBP-5: a dual role for IGFBP-5. Journal of Cellular Physiology 177 47-57.

Florini JR, Ewton DZ \& Coolican SA 1996 Growth hormone and the insulin-like growth factor system in myogenesis. Endocrine Reviews 17 481-517.

Gerrard DE, Okamura CS \& Grant AL 1999 Expression and location of IGF binding proteins-2, -4 , and -5 in developing fetal tissues. Journal of Animal Science 77 1431-1441.

Granata R, Broglio F, Migliorino D, Cutrupi S, Baldanzi G, Sireno M, Fubini A, Grazian A, Ghigo E \& Pucci A 2000 Neonatal and adult human heart tissues from normal subjects and patients with ischemic, dilated or hypertrophic cardiomyopathy express insulin-like growth factor binding protein-3 (IGFBP-3). Journal of Endocrinological Investigation 23 724-726.

Hembree JR, Hathaway MR \& Dayton WR 1991 Isolation and culture of porcine myogenic cells and the effect of insulin, IGF-1 and sera on protein turnover in porcine myotube cultures. Journal of Animal Science 69 3241-3250.

Hembree JR, Pampusch MS, Yang F, Causey JL, Hathaway MR \& Dayton WR 1996 Cultured porcine myogenic cells produce insulin-like growth factor binding protein-3 (IGFBP-3) and transforming growth factor beta-1 stimulates IGFBP-3 production. Journal of Animal Science 74 1530-1540.

Hwa V, Oh Y \& Rosenfeld RG 1999 The insulin-like growth factor-binding protein (IGFBP) superfamily. Endocrine Reviews 20 $761-787$ 
James PL, Stewart CEH \& Rotwein P 1996 Insulin-like growth factor binding protein -5 modulates muscle differentiation through an insulin-like growth factor-dependent mechanism. Journal of Cell Biology 133 683-693.

Jennische E \& Hall CM 2000 Expression and localisation of IGF-binding protein mRNAs in regenerating rat skeletal muscle. Acta Pathologica, Microbiologica et Immunologica Scandinavica 108 747-755.

Johnson BJ, White ME, Hathaway MR \& Dayton WR 1999 Decreased steady-state insulin-like growth factor binding protein-3 (IGFBP-3) mRNA level is associated with differentiation of cultured porcine myogenic cells. Journal of Cellular Physiology 179 237-243.

Johnson BJ, White ME, Hathaway MR \& Dayton WR 2003 Effect of differentiation on levels of insulin-like growth factor binding protein mRNAs in cultured porcine embryonic myogenic cells. Domestic Animal Endocrinology 24 81-93.

Jones JI \& Clemmons DR 1995 Insulin-like growth factors and their binding proteins: biological actions. Endocrine Reviews 16 3-34.

Kveiborg M, Flyvbjerg A, Eriksen EF \& Kassem M 2001 Transforming growth factor- $\beta 1$ stimulates the production of insulin-like growth factor-I and insulin-like growth factor-binding protein-3 in human bone marrow stromal osteoblast progenitors. Journal of Endocrinology 169 549-561.

Laemmli UK 1970 Cleavage of structural proteins during the assembly of the head of bacteriophage T4. Nature 227 680-685.

Lawlor MA \& Rotwein P 2000 Coordinate control of muscle cell survival by distinct insulin-like growth factor activated signaling pathways. Journal of Cell Biology 151 1131-1140.

McCusker RH \& Novakofski J 2004 Zinc partitions IGFs from soluble IGF binding proteins (IGFBP)-5, but not soluble IGFBP-4, to myoblast IGF type 1 receptors. Journal of Endocrinology $\mathbf{1 8 0}$ 227-246.

Meadows KA, Holly JM \& Stewart CE 2000 Tumor necrosis factor-alpha-induced apoptosis is associated with suppression of insulin-like growth factor binding protein-5 secretion in differentiating murine skeletal myoblasts. Journal of Cellular Physiology 183 330-337.

Pampusch MS, Hembree JR, Hathaway MR \& Dayton WR 1990 Effect of transforming growth factor beta on proliferation of L6 and embryonic porcine myogenic cells. Journal of Cellular Physiology 143 524-528.

Ricort JM \& Binoux M 2002 Insulin-like growth factor-binding protein-3 activates a phosphotyrosine phosphatase. Effects on the insulin-like growth factor signaling pathway. Journal of Biological Chemistry 277 19448-19454.

Sanger F, Nicklen S \& Coulson AR 1977 DNA sequencing with chain-termination inhibitiors. PNAS 74 5463-5467.

SAS 2001 SAS user's guide: statistics. Cary, NC: SAS Institutes Inc.
Schedlich LJ, Young TF, Firth SM \& Baxter RC 1998 Insulin-like growth factor-binding protein (IGFBP)-3 and IGFBP-5 share a common nuclear transport pathway in T47D human breast carcinoma cells. Journal of Biological Chemistry 273 18347-18352.

Schedlich LJ, Le Page SL, Firth SM, Briggs LJ, Jans DA \& Baxter RC 2000 Nuclear import of insulin-like growth factor binding protein-3 (IGFBP-3) and IGFBP-5 is mediated by the importin $\beta$ subunit. Journal of Biological Chemistry 275 23462-23470.

Schneider MR, Zhou R, Hoeflich A, Krebs O, Schmidt J, Mohan S, Wolf E \& Lahm H 2001 Insulin-like growth factor-binding protein-5 inhibits growth and induces differentiation of mouse osteosarcoma cells. Biochemical and Biophysical Research Communications 288 435-442.

Schneider MR, Wolf E, Hoeflich A \& Lahm H 2002 IGF-binding protein-5: flexible player in the IGF system and effector on its own. Journal of Endocrinology 172 423-440.

Tureckova J, Wilson EM, Cappalonga JL \& Rotwein P 2001 Insulin-like growth factor-mediated muscle differentiation. collaboration between phosphatidylinositol 3-kinase-akt-signaling pathways and myogenin. Journal of Biological Chemistry 276 39264-39270.

Wabitsch M, Heinze E, Debatin KM \& Blum WF 2000 IGF-I- and IGFBP-3-expression in cultured human preadipocytes and adipocytes. Hormone and Metabolic Research 32 555-559.

White ME, Diao R, Hathaway MR, Mickelson J \& Dayton WR 1996 Molecular cloning and sequence analysis of the porcine insulin-like growth factor binding protein-5 complementary deoxyribonucleic acid. Biochemical and Biophysical Research Communications 218 248-253.

Xu Q, Li S, Zhao Y, Maures TJ, Yin P \& Duan C 2004 Evidence that IGF binding protein-5 functions as a ligand-independent transcriptional regulator in vascular smooth muscle cells. Circulation Research 94 E46-E54.

Yang F, Johnson BJ, White ME, Hathaway MR \& Dayton WR 1999 Effect of insulin-like growth factor (IGF)-I and Des (1-3) IGF-I on the level of IGF binding protein-3 and IGF binding protein-3 mRNA in cultured porcine embryonic muscle cells. Journal of Cellular Physiology 178 227-234.

Yi Z, Hathaway MR, Dayton WR \& White ME 2001 Effects of growth factors on insulin-like growth factor binding protein (IGFBP) secretion by primary porcine satellite cell cultures. Journal of Animal Science 79 2820-2826.

Yin P, Xu Q \& Duan C 2004 Paradoxical actions of endogenous and exogenous insulin-like growth factor-binding protein-5 revealed by RNA interference analysis. Journal of Biological Chemistry 279 32660-32666.

Received 21 December 2004

Accepted 17 January 2005 